\title{
Reprezentacija islama i muslimana u hrvatskim dnevnim novinama od 1990. do 2006. godine
}

\section{Goran Goldberger}

\author{
Institut za društvena istraživanja u Zagrebu, Hrvatska \\ e-mail:goran@idi.hr
}

\begin{abstract}
SAŽETAK U ovom radu autor predstavlja globalni i hrvatski društveni kontekst u koji su uronjeni islam i muslimani, zatim način njihove reprezentacija u medijima te cilj i metodologiju ovog istraživanja. Analiza sadržaja hrvatskih dnevnih novina u dvama razdobljima novije hrvatske povijesti (1990. - 1998. i 1999. - 2006.) pokazuje da su one značajan prostor u kojem se stvara javna slika o djelatnostima muslimana i islama u Hrvatskoj i svijetu, a koja je uvjetovana događajima u konkretnom razdoblju i prostoru. Novine tematski izražavaju politizaciju islama i širi društveno-politički kontekst. U prvom razdoblju najprisutnija je tema rat, ratni zločini i suđenje, a u drugom ljudska i vjerska prava, nesnošljivost i prosvjedi, uz najveći porast teme terorizma i rata protiv terorizma. Dok je u prvom razdoblju fokus podjednako bio na Hrvatskoj i zemljama bivše Jugoslavije, u drugom raste internacionalni fokus na Europu, ali i svijet. Novinari su koristili strategiju rekontekstualizacije, ali su i širili shvaćanje da su autohtoni muslimani u Hrvatskoj mogući most za dijalog Europe i muslimanskog svijeta.
\end{abstract}

Ključne riječi: hrvatske dnevne novine, analiza sadržaja, identitet, demokratizacija, nacionalizam, deprivatizacija i politizacija religije, politički islam, fundamentalizam.

\section{Uvod}

Od 1970-ih sve je prisutnija slika umiješanosti velikih religijskih tradicija (Pace, 2009.) i njihovih fundamentalističkih pokreta ${ }^{1}$ u društvene sukobe, a ponajviše islama i muslimana. Ipak, ta sklonost povezivanja religije $s$ netolerancijom i nasilnim konfliktima zanemaruje doprinos modernih sekularnih vlasti i ideologija takvim procesima u 20. stoljeću (Asad, 1997.:187-188; Casanova, 2008.:66-67). Nakon totalitarnog boljševizma i etno-nacionalističkih i kleriko-autoritarnih pokreta (fašizam i nacizam) fundamentalizam je treći neuspjeh modernizacije i sekularizacije (Almond, Appleby i Sivan, 2003.:5).

1 O fundamentalizmu i fundamentalističkim pokretima vidi u Almond, Appleby i Sivan (2003.), Berger (1999.), Casanova (2001.), Hunt (2003.), Kulenović (2008.) te Matić i Bilandžić (2010.). 
Na sliku umiješanosti islamske tradicije u sukobe utječu događaji koji se nadovezuju na (de)kolonizacijske procese, izraelsko-arapske ratove te islamsku revoluciju Ayatollaha Khomeinija u Iranu 1979. godine. Oni uključuju oružane sukobe u arapskim i muslimanskim zemljama te Bosni i Hercegovini ( $\mathrm{BiH})$, ali i terorističke napade radikalnih islamističkih pokreta u SAD-u i EU, globalni rat protiv terorizma, prosvjede muslimana zbog vrijeđanja islama u SAD-u i EU te nedavne „facebook prosvjede“, nemire i ratne sukobe u Tunisu, Libiji, Egiptu ili Siriji. ${ }^{2}$

Za zapad, većina navedenih događaja pokazatelji su opasnosti islama kao protivnika demokracije, slobode govora, ljudskih prava i modernih država, dok su „facebook prosvjedi“ i sukobi u Tunisu, Libiji, Egiptu i Siriji pokazatelji procesa demokratizacije. Kao globalna transnacionalna religijska zajednica i dijaspora islam je izazovan u odnosu na koncept separacije religije i države, kulturu i identitet zapadnih (kršćanskih) društava, integraciju muslimanskih imigranata u demokratska, sekularna i multikulturalna društva te promjenu imigracijske politike i sigurnosnih prioriteta usmjerenih diskursom „islamskog terorizma“ ili „islamskog fundamentalizma“ (Abbas, 2001.; An-Náim, 1999.; Asad, 1997.; Casanova, 2001.; 2005.; 2008.; Jackson, 2007.; Kovač, 2009.; Kuenzlen, 2009.; Savage, 2004.; Turner, 2010.).

U takvom kontekstu ne dolazi samo do procesa revitalizacije i deprivatizacije religije, već i njene politizacije i povezanosti s kolektivnim identitetima (Casanova, 1994.; Pace, 2009.; Robertson, 1989.; Vrcan, 2001.). Religija ulazi u prostor javnog jezika politike identiteta (nudi utemeljiteljski mit kolektivnih identiteta) i kolektivnog sjećanja (nudi narativ žrtve i mučeništva) kojima društveno-politički pokreti potvrđuju zajedničku vrijednost nacionalne, etničke i religijske zajednice i ugroženost od neprijatelja protiv kojega se treba boriti i ratovati (Pace, 2009.).

U muslimanskom svijetu društvo i tradicija su u krizi, a manifestira se i radikalni, regresivni i antagonistički fundamentalistički pokret kao jedan oblik političkog islama (An-Náim, 1999.; Asad, 1997; Kulenović, 2008.; Matić, 2011.). Karakteristika je njegove cjeline da kao društveni, politički i religijski pokret teži održavanju ili stjecanju vlasti. Na službenom islamu autoritarni režimi temelje legitimitet, dok oporbenim islamom suvremene islamističke stranke i pokreti nude promjene. Islamizam postaje osnova za korekciju nejednakosti i uključivanje isključenih skupina, odgovor je na diferencijaciju i strukturalnu krizu društva i kao fundamentalizam dio je moderne politike i države prisutan u procesu stvaranja nacionalne države (An-Náim, 1999.; Asad, 1997.; Casanova, 2001.; 2005.; 2008.; Kulenović, 2008.; Matić, 2011.; Matić i Bilandžić, 2010.; Shadid i van Koningsveld, 2002.).

Ipak, jedan je od glavnih razloga tenzija u odnosima zapada i muslimanskog svijeta pojednostavljeni informacijski servis. Za medije su muslimani glavna tema i time oni

2 Još jedan značajan element je i porast muslimana. U svijetu danas ima oko 1.620.000.000 muslimana (23,4\%). Islam je druga najveća religija nakon kršćanstva, pa i u nekim državama zapadne Europe u kojoj muslimani čine 6\% stanovništva. (Preuzeto 12. 08. 2012.: http:// en.wikipedia.org/wiki/List_of_countries_by_Muslim_population). 
Šire i zadržavaju negativnu sliku o njima: 1) predstavljaju statični kulturalni koncept (klasična islamska kultura objašnjava djelovanje i stavove muslimana u modernom svijetu); 2) predstavljaju izbor sadržaja i izgled priloga (spominju etničku ili religijsku pripadnost onih koji počine zločin te klasificiraju regionalne ili etničke konflikte kao religijske) (Shadid i van Koningsveld, 2002.:188-189).

U zapadnim medijima prisutan je anti-muslimanski diskurs, islamofobija i rasizam koji doprinose društvenoj diskriminaciji, marginalizaciji, nejednakosti i isključivanju muslimana (Abbas, 2001.; Ameli i sur., 2007.; Hussain, 2000.; Richardson, 2001.; 2006.; Saeed, 2007.). Izvještavanje je dominantno negativno (Ali i Khalid, 2008.) i fokusira se na muslimane kao opasnost (terorizam), problem (razlike u vrijednostima) ili oboje (muslimanski ekstremizam općenito) (Moore, Mason i Lewis, 2008.). Prema Kabiru (2006.:326), medijska reprezentacija muslimana bez uravnoteženog izvještavanja usmjerava se na islamističke militante, čime se efektno demoniziraju svi muslimani. Uravnoteženiji je prikaz u Poljskoj (Nalborczyk, 2004.) te u Bosni i Hercegovini gdje ovisi o nacionalnosti njihove publike (Marko, 2009.).

S obzirom na navedeni društveni kontekst muslimana na zapadu i u muslimanskom svijetu (fundamentalizam, terorizam, imigracija, islamizam), prisutne su negativnosti u medijskim slikama o muslimanima kao problemu. Postavlja se i pitanje kakva je medijska slika o njima u Hrvatskoj, s obzirom na njihov manjinski položaj.

Raspadom Jugoslavije i ratom dolazi do reorganizacije Islamske zajednice. 1916. godine islam je priznat u Hrvatskoj, gdje danas ima oko 60000 muslimana. Islamska zajednica u Hrvatskoj u sastavu je Rijaseta Islamske zajednice BiH, a 2002. potpisala je ugovor s Vladom RH. Prema popisu stanovništva iz 2001. godine, muslimani su treća vjerska skupina (1,28\%), a najviše ima Bošnjaka (0,47\%) i Albanaca $(0,34 \%)$ (http://www.dzs.hr).

U Hrvatskoj su muslimani prisutni u javnom i vjerskom životu i međureligijskom dijalogu. Sadržaj internetskih stranica Islamske zajednice u Hrvatskoj podržava ovu tvrdnju, a prije svega video Islam i muslimani u Hrvatskoj, monografija o zagrebačkoj džamiji, neki bilteni te vijesti od 2010. do 2012. godine o međureligijskom dijalogu i susretima teologa na predstavljanju knjiga, obljetnici proboja logoraša iz Jasenovca ili susretima u zagrebačkoj džamiji (http://www.islamska-zajednica.hr). Štoviše, u 2011. tadašnji predsjednik Mešihata Islamske zajednice u Hrvatskoj muftija Ševko ef. Omerbašić, kao i u 2012. novoizabrani predsjednik Mešihata muftija Aziz ef. Hasanović, izjavljuju da je položaj muslimana u Hrvatskoj na zavidnoj razini i da može biti primjer Europi kako treba riješiti pitanje islama.

\section{Istraživačko pitanje, cilj i hipoteza}

Nakon nekoliko uvodnih opaski o spoznaji vezanoj uz fenomen islama u modernom razdoblju u svijetu, ovdje je potrebno ukratko prikazati osnovno pitanje, cilj i hipotezu istraživanja. 
1. U ovom radu postavljeno je sljedeće osnovno istraživačko pitanje:

Koliko su i na koji način hrvatske dnevne novine reprezentirale djelovanje muslimana i islama u Hrvatskoj i svijetu u društvenom kontekstu tranzicije i demokratizacije? Njega prati i jedno potpitanje: Razlikuje li se njihova reprezentacija u dvama razdobljima novije hrvatske povijesti?

2. Na osnovi istraživačkog pitanja postavljen je i osnovni cilj rada:

U njemu će se dati općenit pregled karakteristika i karaktera reprezentacije muslimana i islama u prilozima dnevnih novina u Hrvatskoj.

Kao posebni ciljevi u radu se će se prikazati sljedeći elementi reprezentacije: 1) učestalost priloga, 2) općenite karakteristike priloga te 3) karakter priloga.

Ovi nam elementi mogu ukazati na okvire informiranja i rasprave u hrvatskim dnevnim novinama kada je riječ o muslimanima i islamu u Hrvatskoj i svijetu. Odnosno, oni nam pokazuju stav novina koji je baziran na njihovoj percepciji stavova populacije i čitatelja, kao i na javnu percepciju o položaju i utjecaju islama i muslimana u društvu.

3. U ovom radu polazi se od sljedeće osnovne hipoteze:

Dnevne su novine značajan javni i diskurzivni prostor u kojem društveni akteri stvaraju javnu sliku i stvarnost o djelatnostima muslimana i islama u Republici Hrvatskoj i drugim državama u svijetu, a koja je prvenstveno uvjetovana događajima u konkretnom razdoblju i geografskom prostoru.

\section{Metodologija}

Analiza sadržaja poruka dnevnih novina o muslimanima i islamu istraživačka je metoda koja se koristi u ovom radu. Ona je u svom osnovnom obliku određena mjerenjem učestalosti pojavljivanja nekog sadržaja i brojanjem određenih varijabli vezanih uz poruke priloga te ima kvantitativan karakter.

Razdoblje istraživanja od 1990. do 2006. godine razdvojeno je na dva dijela:

1) U prvom (1990. - 1998.) se društveni kontekst odnosi na Domovinski rat i rat u $\mathrm{BiH}$ te uspostavljanje nacionalne samostalnosti i pune suverenosti Hrvatske kojim se potvrdila nacionalna država i dominantni nacionalni identitet. Tada dolazi i do potpisivanja četiriju međunarodnih ugovora između Svete Stolice i RH kojima se utvrdio položaj dominantne crkve i religijskog identiteta u Hrvatskoj.

2) U drugom (1999. - 2006.) se društveni kontekst odnosi na dvije promjene vlasti, otvaranje Hrvatske prema integracijama u EU i NATO, prihvaćenje Zakona o pravnom položaju vjerskih zajednica te potpisivanje šest ugovora između države i 15 vjerskih zajednica. Tada dolazi i do terorističkih napada u SAD-u i EU koji se povezuju s islamističkim skupinama.

Razdoblja se preklapaju s razlikama hrvatskog društveno-političkog konteksta u dvjema dekadama. U prvoj se stvara izolirana, autoritarna i etnički homogena drža- 
va bazirana na nacionalnoj integraciji, tradicionalnim vrijednostima i deficitu demokratizacije, dok u drugoj dolazi do veće demokratizacije društva, slobode medija i zaštite ljudskih i manjinskih prava (Ilišin i Radin, 2007.).

Uzorak istraživanja sastoji od svih brojeva Novog lista, Slobodne Dalmacije, Večernjeg lista i Vjesnika, odnosno od cjelokupne zbirke njihovih priloga o muslimanima i islamu koja je prikupljena iz press-clippinga Hrvatske informacijske baze. U istraživanju je jedinica analize novinski prilog, a jedinica sadržaja tema priloga.

Prisutne su i druge varijable značajne za interpretaciju priloga. Općenite karakteristike priloga odnose se na dnevne novine, razdoblje, vrstu, veličinu, prostornu dimenziju i temu, a karakter priloga na orijentaciju i diskurs.

\section{Rezultati}

U ovom dijelu rada predstavljaju se rezultati ukrštanja varijabli priloga koji se odnose na reprezentaciju muslimana i islama u dvama razdobljima novije hrvatske povijesti. Oni će pokazati (1) učestalost, (2) općenite karakteristike i (3) karakter priloga, odnosno reprezentacije muslimana i islamskih zajednica u dnevnim novinama u Hrvatskoj.

\subsection{Učestalost priloga}

Učestalost priloga o muslimanima i islamu u dnevnim novinama indikator je pulsa javnosti, odnosno medijskog i šireg interesa za teme i aktivnosti koje se povezuju s njima u Hrvatskoj i svijetu, ali i o značaju i utjecaju koje im društvo pridaje u tom kontekstu. U tablici 1. nalaze se rezultati zastupljenosti muslimana i islama u prilozima po razdobljima.

Tablica 1.

Broj priloga dnevnih novina po razdobljima (f i \%)

\begin{tabular}{|c|c|c|c|}
\hline \multirow{2}{*}{ Dnevne novine } & \multicolumn{2}{|c|}{ Razdoblja } & \multirow{2}{*}{ Ukupno } \\
\cline { 2 - 3 } & $\mathbf{1 9 9 0 . - 1 9 9 8 .}$ & $\mathbf{1 9 9 9 . - 2 0 0 6 .}$ & \\
\hline \multirow{2}{*}{ Vjesnik } & 82 & 88 & 170 \\
& $44,3 \%$ & $27,1 \%$ & $33,3 \%$ \\
\hline \multirow{2}{*}{ Novi list } & 18 & 104 & 122 \\
& $9,7 \%$ & $32,0 \%$ & $23,9 \%$ \\
\hline \multirow{2}{*}{ Večernji list } & 57 & 63 & 120 \\
& $30,8 \%$ & $19,4 \%$ & $23,5 \%$ \\
\hline \multirow{2}{*}{ Slobodna Dalmacija } & 28 & 70 & 98 \\
& $15,1 \%$ & $21,5 \%$ & $19,2 \%$ \\
\hline \multirow{2}{*}{ Ukupno } & 185 & 325 & 510 \\
& $100,0 \%$ & $100,0 \%$ & $100,0 \%$ \\
\hline
\end{tabular}


Ukupno se pojavilo 510 priloga, a najviše u Vjesniku $(33,3 \%)$ i manje u Novom listu (23,9\%), Večernjem listu (23,5\%) i Slobodnoj Dalmaciji (19,2\%). U prvom razdoblju pojavilo ih se 185 (36,3\%), a najviše u Vjesniku (44,3\%), dok ih se u drugom pojavilo 325 (63,7\%), a najviše u Novom listu (32,0\%). Rezultati pokazuju da dolazi do promjene, odnosno do većeg porasta zastupljenosti priloga u drugom razdoblju. Vjerojatni uzrok ove promjene povezan je sa širim društveno-političkim kontekstom u Hrvatskoj i svijetu.

U Hrvatskoj je prisutna veća demokratizacija društva i zaštita ljudskih prava nakon promjene vlasti 2001. godine, ali i konsolidacija demokracije (Ilišin i Radin, 2007.). Ona se otvara i teži ulasku u NATO i EU, a normalizacija odnosa ublažava ratne poteškoće u njenom odnosu s manjinskim zajednicama. Zaštita ljudskih i vjerskih prava u Hrvatskoj i BiH važna je tema. Raspravlja se i o zakonu o pravnom položaju vjerskih zajednica u Hrvatskoj i o ugovoru koji se treba potpisati s Islamskom zajednicom. U javnosti je naglašen nedostatak vjerskih objekata i problem oko njihove izgradnje, a posebno u Primorsko-goranskoj županiji oko izgradnje džamije s minaretom u Rijeci koja je dovela do zahuktale rasprave i otpora među političarima, braniteljima i lokalnim stanovništvom. ${ }^{3}$

U svijetu su teroristički napadi al-Qaide u SAD-u, Velikoj Britaniji i Španjolskoj usmjerili pažnju medija na fundamentalizam i rat protiv terorizma koji je doveo do problematiziranja muslimanske migracije na zapad, kršenja njihovih ljudskih prava kao i uspostavljanja zatvora u bazi Guantanamo na Kubi. Objavljivanje karikatura proroka Muhameda, zabrane nošenja marama u školama i nesmotrena izjava pape Benedikta XVI. 2006. godine u Regensburgu neke su od europskih reakcija na terorizam radikalnih islamista. Ovi događaji neki su od pokazatelja promjene sigurnosnih prioriteta zapada usmjerenih problematičnim diskursom „islamskog terorizma“ i naracijama da su nasilje i terorizam dio islama, da su motivirani religijskim uzrocima, da su ogromna opasnost za sigurnost zapada kao i da iskorištavaju dobrotvorna društva i nevladine organizacije radi financiranja terorističkog djelovanja (Jackson, 2007.).

Također, Vjesnik više informira javnosti o islamu od ostalih novina koje su privatizirane 1990-ih (Novi list, Večernji list, Slobodna Dalmacija). Međutim, u najzastupljenijoj novini prvog razdoblja (Vjesnik) bilježi se najveći pad u drugom (17\%), dok se kod najmanje zastupljene (Novi list) bilježi najveći porast (22\%). Čini se da su manifestacije islama u drugom razdoblju u hrvatskom i globalnom širem društvenopolitičkom kontekstu tematski magnet za medije u ovakvim okolnostima. Ipak, propadanje Vjesnika pod političkim utjecajem vladajućih te tema izgradnje džamije u Rijeci i drugim gradovima koju je Novi list opširno obrađivao doprinijele su većoj zastupljenosti islamskih zajednica u Novom listu nego u Vjesniku.

3 Ipak, 2009. počela je izgradnja Džamonjine džamije u Rijeci, a svečano otvorenje je planirano krajem 2012. 


\subsection{Općenite karakteristike priloga}

Općenite karakteristike priloga indikator su načina na koji dnevne novine informiraju javnost o djelatnostima muslimana i islama u nacionalnom i internacionalnom okruženju te koje su teme uključene u njihovoj reprezentaciji. U tablici 2. nalaze se rezultati zastupljenosti vrsta priloga po razdobljima.

Tablica 2.

Vrsta priloga po razdobljima (f i \%)

\begin{tabular}{|c|c|c|c|}
\hline \multirow{2}{*}{$\begin{array}{l}\text { Vrsta priloga } \\
1990 .-1998 .\end{array}$} & \multicolumn{2}{|c|}{ Razdoblja } & \multirow{2}{*}{ Ukupno } \\
\hline & 1999.-2006. & & \\
\hline Izvještaj & $\begin{array}{c}37 \\
20,0 \%\end{array}$ & $\begin{array}{c}166 \\
51,1 \%\end{array}$ & $\begin{array}{c}203 \\
39,8 \%\end{array}$ \\
\hline Vijest & $\begin{array}{c}80 \\
43,2 \%\end{array}$ & $\begin{array}{c}74 \\
22,8 \%\end{array}$ & $\begin{array}{c}154 \\
30,2 \%\end{array}$ \\
\hline Intervju & $\begin{array}{c}34 \\
18,4 \%\end{array}$ & $\begin{array}{c}26 \\
8,0 \%\end{array}$ & $\begin{array}{c}60 \\
11,8 \%\end{array}$ \\
\hline Komentar & $\begin{array}{c}18 \\
9,7 \%\end{array}$ & $\begin{array}{c}30 \\
9,2 \%\end{array}$ & $\begin{array}{c}48 \\
9,4 \%\end{array}$ \\
\hline Pisma & $\begin{array}{c}6 \\
3,2 \%\end{array}$ & $\begin{array}{c}7 \\
2,2 \%\end{array}$ & $\begin{array}{c}13 \\
2,5 \%\end{array}$ \\
\hline Kolumna & $\begin{array}{c}4 \\
2,2 \%\end{array}$ & $\begin{array}{c}8 \\
2,5 \%\end{array}$ & $\begin{array}{c}12 \\
2,4 \%\end{array}$ \\
\hline Osvrt & $\begin{array}{c}3 \\
1,6 \%\end{array}$ & $\begin{array}{c}8 \\
2,5 \%\end{array}$ & $\begin{array}{c}11 \\
2,2 \%\end{array}$ \\
\hline Reportaža & $\begin{array}{c}1 \\
0,5 \%\end{array}$ & $\begin{array}{c}3 \\
0,9 \%\end{array}$ & $\begin{array}{c}4 \\
0,8 \%\end{array}$ \\
\hline Prikaz & $\begin{array}{c}1 \\
0,5 \%\end{array}$ & $\begin{array}{c}1 \\
0,3 \%\end{array}$ & $\begin{array}{c}2 \\
0,4 \%\end{array}$ \\
\hline Ostalo & $\begin{array}{c}1 \\
0,5 \%\end{array}$ & $\begin{array}{c}2 \\
0,6 \%\end{array}$ & $\begin{array}{c}3 \\
0,6 \%\end{array}$ \\
\hline Ukupno & $\begin{array}{c}185 \\
100,0 \%\end{array}$ & $\begin{array}{c}325 \\
100,0 \%\end{array}$ & $\begin{array}{c}510 \\
100,0 \%\end{array}$ \\
\hline
\end{tabular}

Najzastupljenije su novinske vrste izvještaji $(39,8 \%)$ i vijesti $(30,2 \%)$, a manje intervjui $(11,8 \%)$, komentari $(9,4 \%)$ i ostalo. U prvom razdoblju najzastupljenije su vijesti (43,2\%), izvještaji (20,0\%) i intervjui (18,4\%), a u drugom izvještaji (51,1\%), vijesti $(22,8 \%)$ i komentari $(9,2 \%)$. Dolazi do znatnijeg porasta zastupljenosti izvještaja (31\%) i pada zastupljenosti vijesti (20\%) i intervjua (10\%). Prevladavaju jednostavniji i informativniji oblici izvještavanja od složenijih. Jedan od mogućih razloga za to stanje medijska je politika hrvatskih novina o religiji, kao i nepostojanje posebne religijske rubrike i religijskog specijalista, slično kako je i u susjednoj BiH (Marko, 2009.). 
U tablici 3. nalaze se rezultati zastupljenosti veličine priloga po razdobljima.

Tablica 3.

Veličina priloga po razdobljima (f i \%)

\begin{tabular}{|c|c|c|c|}
\hline \multirow{2}{*}{$\begin{array}{c}\text { Veličina } \\
\text { Priloga }\end{array}$} & \multicolumn{2}{|c|}{ Razdoblja } & \multirow{2}{*}{ Ukupno } \\
\cline { 2 - 3 } & $\mathbf{1 9 9 0 . - 1 9 9 8 .}$ & $\mathbf{1 9 9 9 . - 2 0 0 6 .}$ & \\
\hline \multirow{2}{*}{ Do 1/4 stranice } & 136 & 209 & 345 \\
& $73,5 \%$ & $64,3 \%$ & $67,6 \%$ \\
\hline \multirow{2}{*}{ Do $1 / 2$ stranice } & 32 & 60 & 92 \\
& $17,3 \%$ & $18,5 \%$ & $18,0 \%$ \\
\hline \multirow{2}{*}{ Više od 1/2 stranice } & 17 & 56 & 73 \\
& $9,2 \%$ & $17,2 \%$ & $14,3 \%$ \\
\hline \multirow{2}{*}{ Ukupno } & 185 & 325 & 510 \\
& $100,0 \%$ & $100,0 \%$ & $100,0 \%$ \\
\hline
\end{tabular}

Najzastupljenija je veličina priloga do četvrtine stranice $(67,6 \%)$, a znatno manje do pola $(18,0 \%)$ i više od pola $(14,3 \%)$ stranice. U obama je razdobljima redoslijed veličina priloga identičan, ali je opala zastupljenost veličine do četvrtine stranice (10\%) i porasla zastupljenost veličine veće od pola stranice (8\%). Islamu je dan manji prostor, i to najčešće u obliku kraćih priloga, ali dulji postaju prisutniji u drugom razdoblju. Najzastupljenije vrste priloga utječu na ovaj rezultat, a dijelom je uvjetovan i većom prisutnošću vizualnih elemenata priloga poput fotografija, tablica, karti ili okvira u drugom razdoblju.

U tablici 4. nalaze se rezultati zastupljenosti prostorne dimenzije priloga po razdobljima.

Tablica 4.

Prostorna dimenzija priloga po razdobljima (f i \%)

\begin{tabular}{|c|c|c|c|}
\hline \multirow{2}{*}{ Prostorna dimenzija } & \multicolumn{2}{|c|}{ Razdoblja } & \multirow{2}{*}{ Ukupno } \\
\cline { 2 - 3 } & \multirow{2}{*}{ 1990.-1998. } & 1999.-2006. & \\
\hline \multirow{2}{*}{ Internacionalna } & 84 & 173 & 257 \\
& $45,4 \%$ & $53,2 \%$ & $50,4 \%$ \\
\hline \multirow{2}{*}{ Domaća } & 79 & 136 & 215 \\
& $42,7 \%$ & $41,8 \%$ & $42,2 \%$ \\
\hline \multirow{2}{*}{ Miješaju se } & 22 & 16 & 38 \\
& $11,9 \%$ & $4,9 \%$ & $7,5 \%$ \\
\hline \multirow{2}{*}{ Ukupno } & 185 & 325 & 510 \\
& $100,0 \%$ & $100,0 \%$ & $100,0 \%$ \\
\hline
\end{tabular}


Najzastupljenija je internacionalna prostorna dimenzija $(50,4 \%)$, nešto manje domaća $(42,2 \%)$, a najmanje se te dimenzije miješaju (7,5\%). U obama razdobljima redoslijed je prostornih dimenzija identičan, ali se razlika između njih malo produbila. U drugom je razdoblju porasla zastupljenost internacionalne prostorne dimenzije (8\%) zbog pada zastupljenosti priloga u kojima se prostorne dimenzije miješaju (7\%). S obzirom na teme terorizma, fundamentalizma i prosvjeda muslimana, fenomen islama postao je prostorno više isključiv i internacionalan, odnosno smanjilo se tematsko preklapanje između domaćeg i internacionalnog islama. Slično kao u Poljskoj (Nalborczyk, 2004.) i BiH (Marko, 2009.), reprezentacija islama u hrvatskim novinama dijelom se zasniva na „senzacijama“ i „kampanjskom“ informativnom obrascu izvještavanja o događajima iz svijeta u koje su uključeni islam i muslimani. Riječ je o prenošenju vijesti iz globalnog medijskog tržišta iz kojeg novine crpe informacije iz svijeta.

Kakvi su rezultati internacionalnih prostora i država priloga po razdobljima?

Najzastupljeniji internacionalni prostor države su bivše Jugoslavije (45,4\%), manje Europe $(26,8 \%)$ i Azije $(13,6 \%)$ te pogotovo ostale. U prvom razdoblju dominiraju države bivše Jugoslavije (87,7\%), a u drugom su najzastupljenije države Europe $(38,1 \%)$ i manje bivše Jugoslavije (21,7\%), Azije (19,0\%) i ostale. U drugom razdoblju fokus na države bivše Jugoslavije znatnije opada (66\%), a raste fokus na države Europe (31\%) i manje Azije i ostale. U prvom razdoblju muslimani i islam fenomen su susjednih država nastalih raspadom bivše Jugoslavije, a u drugom su fenomen u Europi i gotovo cijelom svijetu. Fenomen islama postao je u geografskom opsegu globalan, ali najprisutniji je prostor zapadne hemisfere u kojoj je islam većinom manjinska religija (osim u Turskoj, BiH i Albaniji), a manje prostor u kojima su muslimani većinsko stanovništvo.

Kakvi su rezultati zastupljenosti domaćeg prostora priloga po razdobljima?

Najzastupljeniji je domaći prostor Hrvatska (55,3\%), a rjeđe makroregionalni centri (22,5\%), Zagreb (18,2\%) i ostalo. U prvom razdoblju dominira Hrvatska (66,3\%), a manje je prisutan Zagreb (19,8\%) i ostalo, dok je u drugom Hrvatska i dalje najzastupljenija (48,0\%), a manje makroregionalni centri $(31,6 \%)$, Zagreb $(17,1 \%)$ i ostalo. U drugom razdoblju fokus na Hrvatsku znatnije opada (18\%) i značajnije raste na makroregionalne centre (22\%), a kod ostaloga nema većih promjena. U Hrvatskoj su muslimani fenomen nacionalne razine i sve više većih urbanih sredina. Fenomen islama u određenoj mjeri postaje geografski decentraliziran, odnosno prelazi s državne i regionalne cjeline na makroregionalne centre, što odgovara i zastupljenosti muslimana u Hrvatskoj. ${ }^{4}$

U tablici 5. nalaze se rezultati zastupljenosti tema priloga po razdobljima.

\footnotetext{
${ }^{4}$ Vidi popis stanovništva Hrvatske iz 2001. i broj muslimana po gradovima/općinama (http:// www.dzs.hr).
} 
Tablica 5.

Tema priloga po razdobljima (f i \%)

\begin{tabular}{|c|c|c|c|}
\hline \multirow{2}{*}{ Tema } & \multicolumn{2}{|c|}{ Razdoblja } & \multirow{2}{*}{ Ukupno } \\
\hline & 1990.-1998. & 1999.-2006. & \\
\hline Obredi, običaji i ceremonije & $\begin{array}{c}30 \\
16,2 \%\end{array}$ & $\begin{array}{c}47 \\
14,5 \%\end{array}$ & $\begin{array}{c}77 \\
15,1 \%\end{array}$ \\
\hline $\begin{array}{c}\text { Ljudska i vjerska prava, nesnošljivost } \\
\text { i prosvjedi }\end{array}$ & $\begin{array}{c}16 \\
8,6 \%\end{array}$ & $\begin{array}{c}57 \\
17,5 \%\end{array}$ & $\begin{array}{c}73 \\
14,3 \%\end{array}$ \\
\hline Dijalog, mirotvorstvo i tolerancija & $\begin{array}{c}16 \\
8,6 \%\end{array}$ & $\begin{array}{c}40 \\
12,3 \% \\
\end{array}$ & $\begin{array}{c}56 \\
11,0 \% \\
\end{array}$ \\
\hline Izgradnja i obnova vjerskih objekata & $\begin{array}{c}10 \\
5,4 \%\end{array}$ & $\begin{array}{c}44 \\
13,5 \% \\
\end{array}$ & $\begin{array}{c}54 \\
10,6 \% \\
\end{array}$ \\
\hline Rat, ratni zločini i suđenje & $\begin{array}{c}51 \\
27,6 \%\end{array}$ & $\begin{array}{c}2 \\
0,6 \%\end{array}$ & $\begin{array}{c}53 \\
10,4 \%\end{array}$ \\
\hline Sloboda vjere i položaj u društvu & $\begin{array}{c}11 \\
5,9 \% \\
\end{array}$ & $\begin{array}{c}22 \\
6,8 \% \\
\end{array}$ & $\begin{array}{c}33 \\
6,5 \% \\
\end{array}$ \\
\hline Terorizam i rat protiv terorizma & $\begin{array}{c}0 \\
0,0 \% \\
\end{array}$ & $\begin{array}{c}33 \\
10,2 \% \\
\end{array}$ & $\begin{array}{c}33 \\
6,5 \%\end{array}$ \\
\hline Kriminal i devijantnost & $\begin{array}{c}16 \\
8,6 \% \\
\end{array}$ & $\begin{array}{c}9 \\
2,8 \% \\
\end{array}$ & $\begin{array}{c}25 \\
4,9 \% \\
\end{array}$ \\
\hline $\begin{array}{l}\text { Odnos učenja i društvenih vrijednosti, } \\
\text { normi i znanosti }\end{array}$ & $\begin{array}{c}6 \\
3,2 \% \\
\end{array}$ & $\begin{array}{c}16 \\
4,9 \% \\
\end{array}$ & $\begin{array}{c}22 \\
4,3 \% \\
\end{array}$ \\
\hline $\begin{array}{l}\text { Društveno-političke promjene } \mathrm{i} \\
\text { socijalni problemi }\end{array}$ & $\begin{array}{c}8 \\
4,3 \%\end{array}$ & $\begin{array}{c}13 \\
4,0 \%\end{array}$ & $\begin{array}{c}21 \\
4,1 \%\end{array}$ \\
\hline Organizacijski i hijerarhijski (re)ustroj & $\begin{array}{c}10 \\
5,4 \% \\
\end{array}$ & $\begin{array}{r}10 \\
3,1\end{array}$ & $\begin{array}{c}20 \\
3,9 \% \\
\end{array}$ \\
\hline Vjeronauk i dušobrižništvo & $\begin{array}{c}6 \\
3,2 \% \\
\end{array}$ & $\begin{array}{c}3 \\
0,9 \% \\
\end{array}$ & $\begin{array}{c}9 \\
1,8 \% \\
\end{array}$ \\
\hline Ugovor & $\begin{array}{c}1 \\
0,5 \% \\
\end{array}$ & $\begin{array}{c}7 \\
2,2 \% \\
\end{array}$ & $\begin{array}{c}8 \\
1,6 \% \\
\end{array}$ \\
\hline $\begin{array}{c}\text { Zakon o pravnom položaju vjerskih } \\
\text { zajednica }\end{array}$ & $\begin{array}{c}0 \\
0,0 \%\end{array}$ & $\begin{array}{c}6 \\
1,8 \% \\
\end{array}$ & $\begin{array}{c}6 \\
1,2 \% \\
\end{array}$ \\
\hline Kontrola, sudske tužbe i odluke & $\begin{array}{c}1 \\
0,5 \% \\
\end{array}$ & $\begin{array}{c}4 \\
1,2 \% \\
\end{array}$ & $\begin{array}{c}5 \\
1,0 \% \\
\end{array}$ \\
\hline Povijest & $\begin{array}{c}0 \\
0,0 \% \\
\end{array}$ & $\begin{array}{c}4 \\
1,2 \% \\
\end{array}$ & $\begin{array}{c}4 \\
0,8 \% \\
\end{array}$ \\
\hline Posjeti i predavanja & $\begin{array}{c}1 \\
0,5 \%\end{array}$ & $\begin{array}{c}3 \\
0,9 \% \\
\end{array}$ & $\begin{array}{c}4 \\
0,8 \% \\
\end{array}$ \\
\hline $\begin{array}{c}\text { Izdavačka djelatnost i obrazovanje } \\
\text { djelatnika }\end{array}$ & $\begin{array}{c}0 \\
0,0 \% \\
\end{array}$ & $\begin{array}{c}3 \\
0,9 \% \\
\end{array}$ & $\begin{array}{c}3 \\
0,6 \% \\
\end{array}$ \\
\hline Normalizacija odnosa i Dayton & $\begin{array}{c}2 \\
1,1 \% \\
\end{array}$ & $\begin{array}{c}1 \\
0,3 \% \\
\end{array}$ & $\begin{array}{c}3 \\
0,6 \% \\
\end{array}$ \\
\hline Povrat imovine & $\begin{array}{c}0 \\
0,0 \%\end{array}$ & $\begin{array}{c}1 \\
0,3 \% \\
\end{array}$ & $\begin{array}{c}1 \\
0,2 \% \\
\end{array}$ \\
\hline Ukupno & $\begin{array}{c}185 \\
100,0 \%\end{array}$ & $\begin{array}{c}325 \\
100,0 \%\end{array}$ & $\begin{array}{c}510 \\
100,0 \%\end{array}$ \\
\hline
\end{tabular}


Najzastupljenije su teme (1) obredi, običaji i ceremonije $(15,1 \%)$ te (2) ljudska i vjerska prava, nesnošljivost i prosvjedi (14,3\%).

(1) Novine redovito informiraju o obrednim djelatnostima koje se odvijaju u okviru značajnih datuma muslimanskog religijskog kalendara. Prije svega značajnih vjerskih blagdana: Bajrama, Kurban-bajrama, rođenja božjeg poslanika Muhameda i hadža u Meku. Tada se prenose i čestitke političara, državnih dužnosnika ili vjerskih vođa drugih vjera. Opisuje se obred, vjerovanja i glavne poruke tijekom klanjanja. U te su poruke uključene i političke poruke, na primjer o ratu u Hrvatskoj i BiH ili o terorizmu u svijetu. Također se izvještava o običajima (obredno klanje bikova, post, hodočašće, bacanje kamenčića na šejtana, nošenja marame kod žena) i svečanim događajima (ceremonija predavanja menšure novoizabranom reis-ul-ulemi Mustafi Ceriću u Sarajevu 1996. godine, otvaranje džamije u Labinu 1998., obljetnica otvorenja zagrebačke džamije 1999., 90. godišnjice islama kao priznate religije u Hrvatskoj 2006. godine). ${ }^{5}$

(2) Novine izvještavaju o ljudskim pravima, odnosu države prema nacionalnim i religijskim identitetima većine i manjina. Prikazani su problemi nejednakosti manjina baziranih na povezanosti nacionalnog i religijskog identiteta. Ova slika prisutna je u Hrvatskoj i BiH, ali i u EU i muslimanskom svijetu. Nju prelama pitanje izgradnje vjerskih objekata, privatizacije i ugrožavanja privatnog vlasništva ili načina života pripadnika manjina. Izvještava se o pravima i običajima, primjerice da muslimanke u javnosti nose maramu u EU, ali i u Istri ${ }^{6}$. Problematiziraju se i njihova kršenja i oblici nesnošljivosti ili vrijeđanja vjere koji su doveli do prosvjeda u muslimanskom svijetu, a prvenstveno su povezani s kontekstom terorizma i ratom zapada protiv terorizma. Tu je riječ o skrnavljenju Kur'ana u zatvoru vojnog kampa Guantanamo na Kubi, govoru pape Benedikta XVI. u Regensburgu u kojem je citirao da je islam vjera koja se širi nasiljem i mačem te objavi karikature proroka Muhameda s bombom na glavi umjesto turbana u tjednim tiskovinama diljem Europe. Karikature su se pojavile i u hrvatskom tjedniku Nacional, uz javne kritike.

Manje su zastupljene teme (3) dijalog, mirotvorstvo i tolerancija (11,0\%), (4) izgradnja i obnova vjerskih objekata $(10,6 \%)$ te (5) rat, ratni zločini i suđenje $(10,4 \%)$.

(3) Novine izvještavaju o mirotvornim nastupima zagrebačkog imama Mustafe Cerića protiv rata u BiH 1991. godine (izabran je za reis-ul-ulemu u Sarajevu 1996.), a 1997. o sudjelovanju muftije Ševka Omerbašića u Budimpešti na mirovnom skupu „Religija i budućnost odnosa među vjerskim zajednicama u BiH, Hrvatskoj i SR Jugoslaviji“. Muftija Omerbašić dobio je nagradu HHO-a za promicanje

5 Za razliku od Hrvatske, islam u Europi većinom nema uređen pravni status, ali je službeno priznat, primjerice, u Austriji 1912., Poljskoj 1936., Belgiji 1974. i Španjolskoj 1989. godine.

6 2001. godine pulski imam Vahid Hadžić tvrdio je da njegova supruga u Puli nije mogla dobiti osobnu iskaznicu s fotografijom na kojoj ima maramu na glavi, unatoč vozačkoj dozvoli izdanoj u Zagrebu s istom fotografijom. Ona je pak potvrdila da je dobila osobnu iskaznicu, ali se namjerno fotografirala bez marame jer uglavnom tako i živi posljednjih godina. 
ljudskih prava i za dijalog među religijama 1998. godine, zalagao se za mirotvorstvo i dijalog s kršćanstvom i zapadom nakon terorističkih napada 2001., a 2003. dobio je nagradu Hrvatske akademske udruge za osobu godine zbog zalaganja za dijalog među religijama. 2006. godine Islamska zajednica iz BiH (reis-ul-ulema Mustafa Cerić) u Islamskom je centru u Zagrebu predstavila „Deklaraciju europskih muslimana“ u kojoj se zalažu za dijalog zapada s europskim islamom. Izvještavalo se i o ekumenskom posjetu pape Benedikta XVI. pravoslavnom patrijarhu Bartolomeju I., a tada je posjetio i Istambul i molio se zajedno s istambulskim muftijom Mustafom Cagricijem u Plavoj džamiji.

(4) Novine izvještavaju o problemima izgradnje i obnove vjerskih objekata kao dijela kulturne i umjetničke baštine države. Izvještavalo se o stanju u Hrvatskoj (prvenstveno o nedostatku muslimanskog groblja i vjerskog prostora te problemu izgradnje džamije u Rijeci), BiH (bujanje gradnje džamija), ali i u svijetu. Raspravljalo se i o financiranju izgradnje džamija i obrazovanja mladih od nevladinih udruga iz Saudijske Arabije, u kojima se problematizirala prisutnost ideja vehabizma u BiH nakon rata. Ona predstavlja najznačajniju temu tematskog sklopa odnosa države i islamske zajednice jer je obnova vjerskih objekata u tranziciji bila jedan od njezinih prioriteta, a pogotovo u $\mathrm{BiH}$ u kojoj je u ratu uništeno mnogo džamija.

(5) Novine izvještavaju o muslimanima koji sudjeluju u ratu i obrani Hrvatske 1991. godine, dok se 1992. počelo raspravljati o ratu u BiH, UN-ovom embargu na oružje i potrebi financijske, humanitarne i druge pomoći ostalih muslimanskih zemalja. Izvještavalo se o zajedničkoj borbi Hrvata i Bošnjaka protiv Srba te prosvjedu zagrebačkog imama Mustafe Cerića zbog logora, ubojstava, silovanja muslimanki i muslimanskog holokausta u ratnoj BiH. Od 1993. do 1995. godine raspravljalo se o predavanju imama Mustafe Cerića o situaciji u $\mathrm{BiH}$ u Abu Dabiju i navodnim optužbama da su Hrvati uvukli muslimane u rat, iako su brojne muslimanske izbjeglice sigurnost našle upravo u Hrvatskoj. Raspravljalo se o humanitarnoj katastrofi i umiranju ljudi od gladi na opkoljenim područjima. Efendija Ševko Omerbašić kritizirao je besmisleni rat Hrvatske i BiH i protjerivanje Hrvata iz Srednje Bosne kao sramotan čin. Optuživao je Owena, Akashija, UN i UNPROFOR za neučinkovitost i odgovornost za zločine u BiH, a pogotovo za Srebrenicu. Iste rasprave vodile su se i u slučaju Islamske zajednice iz $\mathrm{BiH}$ : o zločinima i ratu, o osvajanju hrvatskih teritorija i rušenju vjerskih objekata, o uništavanju džamija u Banjaluci i Tomislavgradu od Srba i Hrvata. U raspravama o ratu u BiH više se izvještavalo o utjecaju Srba nego Hrvata.

Ostalih 15 tema još je slabije zastupljeno, a među njima najviše sloboda vjere i položaj u društvu te terorizam i rat protiv terorizma (svaka 6,5\%).

U prvom razdoblju prisutno je 15 tema. Najzastupljenija je rat, ratni zločini i suđenje $(27,6 \%)$, a slabije obredi, običaji i ceremonije $(16,2 \%)$, dijalog, mirotvorstvo i tolerancija $(8,6 \%)$, ljudska i vjerska prava, nesnošljivost i prosvjedi $(8,6 \%)$, kriminal i devijantnost $(8,6 \%)$ i ostale. U drugom razdoblju prisutno je 20 tema. Najzastupljenija je ljudska i vjerska prava, nesnošljivost i prosvjedi (17,5\%), a slabije obredi, običaji i ceremonije $(14,5 \%)$, izgradnja i obnova vjerskih objekata $(13,5 \%)$, dijalog, 
mirotvorstvo i tolerancija (12,3\%), terorizam i rat protiv terorizma $(10,2 \%)$ i ostale. Možemo zaključiti da u prvom razdoblju reprezentacija islama ukazuje na trendove transformacije i raspada jugoslavenskog društva, deprivatizacije i politizacije religije te njenu povezanost s kolektivnim identitetima (Casanova, 1994.; Robertson, 1989.; Vrcan, 2001.). Velike religijske tradicije ili "granične religije“ uključene su u politike identiteta, društvene sukobe i ratove u bivšoj Jugoslaviji. Oni se zasnivaju na teritoriju, žrtvovanju sebe i neprijatelja, ubojstvima muškaraca i silovanju žena, „etničkom čišćenju“, kao i rušenju religijskih simbola onog „drugoga“ (Pace, 2009.), odnosno religijskom pobijanju u obliku religijske „simboličke de-kontaminacije“ i „simboličke okupacije“ (Vrcan, 2006.:216-217), uz kršenje manjinskih prava. Pri tome se posezalo i za povijesnim naslijeđem Otomanskog osvajanja Balkana, Hrvatskom kao „predziđem kršćanstva“, kao i zabrinutošću zbog stvaranja islamske države u BiH. Prisutna je i religiozna slika muslimana i islamske zajednice: vjerski obredi i običaji, dijalog i mirotvorstvo tijekom rata u Hrvatskoj i $\mathrm{BiH}$, (re)organizacija i izbor vjerskih djelatnika te nastavak života i djelovanja u novonastalim državama. Muslimani su pokazali zahvalnost za veće vjerske slobode te zahtjeve za izgradnjom džamija u Osijeku i Rijeci, ali i u BiH, uz problematiziranje obima gradnje i iskorištavanje dobrotvornih društava i nevladinih organizacija (Jackson, 2007.) radi financiranja i uvoženja stranog islamizma (vehabizam) ${ }^{7}$.

U drugom razdoblju reprezentacija i dalje ukazuje na trend politizacije islama. Teroristički napadi islamista u ideji mučeništva u sebi objedinjuju lik domoljuba, sveca i ratnika (Pace, 2009.), ali su proizveli snažnu reakciju zapada - rat protiv terorizma globalno. Istovremeno dolazi do proliferacije pseudokrižarske retorike, što je kontinuitet diskursa o križarskim ratovima i islamu kao europskom „drugom“ koji se sastoji od slika iz orijentalističke škrinje (Tafra, 2009.:709). Dolazi do promjene sigurnosnih prioriteta usmjerenih diskursom „islamskog terorizma“ (Jackson, 2007.), ali i sve većeg značaja problema demonizacije (Kabir, 2006.) i integracije muslimana na zapadu (Savage, 2004.; Turner, 2010.). Prisutne su afere koje ukazuju na netoleranciju prema muslimanima u Europi i SAD-u. Tu je riječ o skrnavljenju Kur'ana, objavi karikature proroka Muhameda, kao i govoru pape Benedikta XVI. u Regensburgu. Ti su događaji prouzročili prosvjede u muslimanskom svijetu. Kod nošenja marama prisutna je ideja slobode izbora koju zagovaraju sekularne vlasti naspram slobode savjesti koju zagovaraju muslimani, a u aferi objava karikature proroka Muhameda, poput afere Rushdiejevih Sotonskih stihova, prisutan je koncept bogohuljenja koji su kritizirali muslimani, dok su sekularisti smatrali da je riječ o slobodi govora (Davie, 2005.).

S ovim temama izjednačile su se teme religijskih vrijednosti, praksi i organizacija. Prvenstveno zbog dijaloških nastojanja pape Benedikta XVI. u Turskoj, koja su uslijedila nakon prosvjeda muslimana zbog njegovog govora u Regensburgu, a manje zbog uobičajeno prisutnih tema obreda, običaja i ceremonija. Također, predstav-

${ }^{7}$ Vehabizam je bio značajna tema i u tiskovinama u BiH (Marko, 2009::190-192). 
ljanje „Deklaracije europskih muslimana“8 u Zagrebu jača shvaćanje da autohtoni muslimani u Hrvatskoj i BiH mogu biti most i poveznica zapada i islamskog svijeta (Kovač, 2009.), pogotovo u kontekstu ulaska Hrvatske u EU. Hrvatski muslimani imaju regulirani status i islam je priznat od 1916. godine, a Islamska zajednica ima potpisan ugovor od zajedničkog interesa s RH od 2002. godine. Takav položaj nema ni Islamska zajednica u BiH. U porastu su i teme vezane uz odnos države i islama, prvenstveno zbog izgradnje i obnove vjerskih objekata te problema vezanih uz izgradnju džamije u Rijeci. Najviše je opala zastupljenost teme rat, ratni zločini i suđenje (27\%), a najviše je porasla zastupljenost tema terorizma i rata protiv terorizma (10\%) te ljudskih i vjerskih prava, nesnošljivosti i prosvjeda (9\%), kao što se moglo i očekivati zbog promijenjenog društvenog konteksta u Hrvatskoj i svijetu. Čini se, ipak, da ovi rezultati potvrđuju jednim dijelom nalaz da su hrvatski novinari koristili strategiju rekontekstualizacije zamijenivši prvu s drugom temom; opredijelili su se za diskurse „rat protiv terorizma“, „Irački rat“, „europski“ i „,neoliberalni“ radi opravdanja nacionalističke ideologije „velike Hrvatske“ i iz nje izvedenih zločina koje su u BiH počinili hrvatski vojnici (Erjavec i Volčić, 2007.).

\subsection{Karakter priloga}

Karakter priloga, odnosno orijentacija i diskurs priloga o muslimanima i islamu indikator su stava javnosti o njihovim djelatnostima u Hrvatskoj i svijetu, kao i percepcije konteksta u kojem jezik daje značenja i upućuje na djelovanje u odnosu na opaženi fenomen. Evo i rezultata orijentacije priloga. Najzastupljenija je neutralna $(77,1 \%)$, a manje negativna $(17,1 \%)$ i pozitivna $(5,9 \%)$ orijentacija. U obama razdobljima redoslijed je zastupljenosti orijentacija priloga identičan, uz manja odstupanja. Rezultati pokazuju da je dominantna neutralna orijentacija $(71,9 \%)$ o islamu, a u drugom je i u blagom porastu (8\%), što je povezano s najprisutnijim vrstama priloga (vijesti i izvještaji). U obama razdobljima negativna je orijentacija (20,5\% i 15,4\%) oko tri puta zastupljenija od pozitivne (7,6\% i 4,9\%). Problematične teme prvog (rat na prostoru Hrvatske i $\mathrm{BiH}$ ) i drugog razdoblja (globalni kontekst terorizma i rata protiv terorizma te kršenja ljudskih i vjerskih prava, nesnošljivosti i prosvjeda, uz nacionalni kontekst izgradnje i obnove vjerskih objekata) čini se da su utjecale na takvu orijentaciju priloga.

Mjerio se i diskurs priloga, odnosno rječnik i terminologija koja u njemu dominira. Najzastupljeniji je društveno-politički (54,7\%), a rjeđe religijsko-filozofski (33,7\%), pravni $(10,6 \%)$ i moralno-devijantni $(1,0 \%)$ diskurs. U obama razdobljima redoslijed

\footnotetext{
8 Ona je predstavljena u Zagrebu 23. veljače 2006. godine. Reis-ul-ulema Mustafa Cerić izrazio je žaljenje zbog terorizma u svijetu i naglasio da ne može prihvatiti ubijanje u ime islama. Veleposlanicima u Hrvatskoj, u kojoj muslimani uživaju puna prava, predao je zahtjev za razvoj islamskih škola, političku slobodu, liberalizaciju imigrantske politike te zaštitu od islamofobije. Europskim muslimanima poručio je da bi trebali za cilj imati novi Westfalski mir i sporazum da su katoličanstvo, protestantizam, islam i judaizam europske religije koje trebaju živjeti u miru i toleranciji. Deklaracijom traži da Europa formalno prizna islam (institucionalizacija islama) i da islam prihvati europske vrijednosti, stečevine i navike življenja.
} 
zastupljenosti diskursa priloga identičan, je ali se u drugom javlja i moralno-devijantni diskurs (1,5\%). U prilozima o islamu većinom je prisutan društveno-politički diskurs (62,2\%), iako opada u drugom razdoblju (12\%). Jezik tog diskursa uključuje naciju i nacionalizam, državu i državotvornost (suverenost), samostalnost, rat i terorizam, migraciju i migrante, manjinu i manjinsko, politiku i izbore, demokraciju i demokratizaciju, pretvorbu, liberalizaciju i privatizaciju tržišta, pluralizaciju i raznolikost, mirovne sporazume i obnovu, nezaposlenost i socijalu. Manje su zastupljeni religijsko-filozofski i pravni diskurs, koji postaje znatnije zastupljen od ostalih u drugom razdoblju (7\%). ${ }^{9}$ Razlog ovakve zastupljenosti diskursa priloga prije svega valja tražiti u najprisutnijim temama. U prilozima prvog razdoblja prisutan je kontekst osamostaljenja republika, rata i raspada Jugoslavije, koji je doveo do veće upotrebe političkog jezika i terminologije u odnosu na teritorijalne pretenzije sukobljenih strana i to posebice u $\mathrm{BiH}$. U drugom razdoblju najveću ulogu odigrala je tema terorizma i rata protiv terorizma i s njom povezana ljudska i vjerska prava, nesnošljivost i prosvjedi, zbog kojih su djelatnosti muslimana i islama ostale unutar okvira političkog jezika i terminologije. Ova druga tema je jednim manjim dijelom, a izgradnja i obnova vjerskih objekata većim, doprinijela većoj zastupljenosti pravnog diskursa.

\section{Zaključak}

Istraživanja medijske reprezentacije islama i muslimana u zapadnim medijima pokazala su islamofobiju, rasizam i anti-muslimanski diskurs koji doprinose društvenoj i ekonomskoj diskriminaciji, marginalizaciji i isključivanju muslimana. Oni su imigrantski, etnički, kulturalni i religijski „drugi“ koji svojim identitetom negiraju identitet i način života domicilnog stanovništva (Abbas, 2001.; Ameli i sur., 2007.; Hussain, 2000.; Richardson, 2001.; 2006.; Saeed, 2007.). Istraživanja u bivšim komunističkim državama, u kojima su muslimani autohtono i tradicionalno prisutno stanovništvo, pokazala su ujednačeniju reprezentaciju, ali i „kampanjski“ i „senzacionalistički“ informativni obrazac izvještavanja o događajima iz svijeta u koje su uključeni muslimani (Marko, 2009.; Nalborczyk, 2004.).

Cilj istraživanja bio je pokazati koliko i na koji su način hrvatske dnevne novine reprezentirale djelovanje muslimana i islama u Hrvatskoj i svijetu te razlikuje li se reprezentacija u dvama novijim razdobljima hrvatske povijesti. Rezultati su potvrdili hipotezu da su novine značajan javni i diskurzivni prostor u kojem akteri stvaraju javnu sliku o djelovanju islama i muslimana u Hrvatskoj i svijetu te da je stvarnost u tom prostoru prvenstveno uvjetovana događajima u konkretnom razdoblju i geografskom prostoru.

9 Religijsko-filozofski diskurs uključuje religioznost, vjerovanje, dušu, bitak, iskon, dijalog, mirotvorstvo, toleranciju, fundamentalizam, post, molitvu, obred i duhovnu obnovu. Pravni diskurs uključuje slobodu vjere i vjeroispovijesti, Ustav i odredbe, ljudska i vjerska prava, zakonske odredbe i pravne regulative, odredbe GUP-a, sudske tužbe i odluke suda, regulaciju i kontrolu običaja zajednice, povrat imovine, zakon o pravnom položaju vjerskih zajednica i ugovor države i islamske zajednice. Moralno-devijantni diskurs uključuje devijantnost, nasilje, kolektivna ubojstva i samoubojstva, teror, militantnost i manipulaciju. 
U prvom razdoblju fokus je prvenstveno usmjeren na prostor Hrvatske i bivše Jugoslavije, transformaciju društva i raspad države, rat u Hrvatskoj i BiH, kao i transformaciju Islamske zajednice u novonastalim državama. U drugom razdoblju fokus se usmjerio na širi prostor Europe i cijelog svijeta, na ljudska i vjerska prava, nesnošljivost i prosvjede i terorizam i rat protiv terorizma te na islamske zajednice iz svijeta.

Po uzoru na zapad i slično kao i u Poljskoj i BiH (Marko, 2009.; Nalborczyk, 2004.), hrvatske su novine u internacionalnim događajima koji uključuju muslimane jednim dijelom pokazale tendenciju preuzimanja njihovog statičnog kulturalnog koncepta islama i klasificiranja regionalnih i etničkih sukoba koji uključuju muslimane kao religijske (Shadid i van Koningsveld, 2002.), čime se islam i muslimani prikazuju kao opasnost i/ili problem (Moore i sur., 2008.). Međutim novine su jednim dijelom obrađivale i konflikte u muslimanskom svijetu kao pokazatelje demokratizacije islamske politike.

S druge strane, u kontekstu država bivše Jugoslavije i Hrvatske, dnevne su novine prikazale utjecaj revitalizacije, deprivatizacije i politizacije religija i islama i njihove povezanosti s kolektivnim identitetima (Casanova, 1994.; Pace, 2009.; Robertson, 1989.; Vrcan, 2001.), pogotovo u okviru pograničnih područja i „granične religije“ (Vrcan, 2006.) koja ulazi u prostor javnog jezika politike identiteta i otvorene ratne sukobe (Pace, 2009.).

Pri tome su novinari kasnije koristili strategiju rekontekstualizacije kroz temu terorizma i rata protiv terorizma radi opravdanja ideologije „velike Hrvatske“ i zločina koje su u BiH počinili hrvatski vojnici (Erjavec i Volčić, 2007.). Isto tako, širili su shvaćanje da su muslimani u Hrvatskoj autohtono, integrirano i tolerantno stanovništvo i sastavni dio zapadne civilizacije i kulture te da mogu poslužiti kao most između muslimanskog svijeta i zapada (Kovač, 2009.), pogotovo u kontekstu ulaska Hrvatske u NATO i pregovora oko ulaska u EU.

Glavni doprinos ovog rada prikaz je rezultata novog istraživanja o reprezentaciji islama i muslimana u dnevnim novinama u Hrvatskoj od 1990. do 2006. godine. Do sada u Hrvatskoj još nije bilo poduzeto ovakvo istraživanje i ovaj rad može biti poticaj u tom smjeru.

Čini se da je prisutna potreba daljnjeg istraživanja medijske reprezentacije islama i muslimana u državama u kojima je prisutan tradicionalni, autohtoni i manjinski muslimanski identitet i njegov utjecaj na identitet većinskog stanovništva, uz osvrt na značaj razine religioznosti u tom kontekstu, jer se čini da veća religioznost u državi utječe na manje negativnu medijsku reprezentaciju islama i muslimanske religioznosti i načina života. 


\section{Literatura}

1. Abbas, T. (2001). Media Capital and the Representation of South Asian Muslims in the British Press: An Ideological Analysis. Journal of Muslim Minority Affairs, 21 (2): 245-257.

2. Ali, S.; Khalid (2008). US Mass Media and Muslim World: Portrayal of Muslim by „Newsweek“ and "Time“. European Journal of Scientific Research, 21 (4): 554-580.

3. Almond, G. A.; Appleby, R. S. and Sivan, E. (2003). Strong Religion: The Rise of Fundamentalism around the World. Chicago: University of Chicago Press.

4. Ameli, S. R.; Marandi, S. M.; Ahmed, S.; Kara, S.; Merali, A. (2007). The British Media and Muslim Representation: The Ideology of Demonization: British Muslims' Expectations of the Government. Wembley: Islamic Human Rights Commision. Pregledano 14. siječnja 2012. (http://www.ihrc.org.uk/file/1903718317.pdf).

5. An-Náim, A. A. (1999). Political Islam in National politics and International Relations, in: Berger Peter L. (Ed.). The Desecularization of the World: Resurgent Religion and World Politics. Grand Rapids: Eerdmans:103-121.

6. Asad, T. (1997). Europe Against Islam: Islam in Europe. The Muslim World, 87 (2): 183-195.

7. Berger, P. L. (1999). The Desecularization of the World: A Global Overview, in: Berger Peter L. (Ed.). The Desecularization of the World: Resurgent Religion and World Politics. Grand Rapids: Eerdmans:1-18.

8. Casanova, J. (2008). The problem of religion and the anxieties of European secular democracy, in: Motzkin Gabriel and Ficher Yochi (Eds.). Religion and Democracy in Contemporary Europe. London: Alliance Publishing Trust:63-74.

9. Casanova, J. (2005). Catholic and Muslim Politics in Comparative Perspectives. Taiwan Journal of Democracy, 1 (2): 89-108.

10. Casanova, J. (2001). Civil Society and religion: Retrospective Reflections on Catholicism and Proaspective Reflections on Islam. Social Research, 68 (4): 10411080 .

11. Casanova, J. (1994). Public Religions in the Modern World. Chicago: University of Chicago Press.

12. Davie, G. (2005). Religija u suvremenoj Europi. Mutacija sjećanja. Zagreb: Golden marketing-Tehnička knjiga.

13. Erjavec, K. and Volčić, Z. (2007). Croatian journalists' narratives on Croatian war crimes in Bosnia-Hercegovina. Caligrama. Pregledano 10. studenog 2011. (http://www.eca.usp.br/caligrama/english/10_karmen.pdf).

14. Hunt, S. J. (2003). Alternative Religions: A Sociological Introduction. Aldershot: Ashgate.

15. Hussain, M. (2000). Islam, Media and Minorities in Denmark. Current Sociology, 48 (4): 95-116.

16. Ilišin, V. i Radin, F. (2007). Mladi u suvremenom hrvatskom društvu, u: Ilišin Vlasta i Radin Furio (Ur.). Mladi: problem ili resurs. Zagreb: IDIZ:13-37.

17. Jackson, R. (2007). Constructing Enemies: 'Islamic Terrorism' in Political and Academic Discourse. Government and Opposition, 42 (3): 394-426.

18. Kabir, N. (2006). Representation of Islam and Muslims in the Australian Media, 2001-2005. Journal of Muslim Minority Affairs, 26 (3): 313-328. 
19. Kovač, T. (2009). Islam kao paradigma suvremenom europskom društvu i kršćanskoj misli. Nova prisutnost, 7 (2): 207-220.

20. Küenzlen, G. (2009). The Other Side of Globalisation: The New Power of Religion as a Cultural and Political Challenge. Synthesis philosophica, 48 (2): 219-231.

21. Kulenović, T. (2008). Politički islam: Osnovni pojmovi, autori i skupine jednog modernog političkog pokreta. Zagreb: VBZ.

22. Marko, D. (2009). Zar na zapadu postoji neki drugi Bog?: stereotipi i predrasude u medijima prema islamu. Sarajevo: Media plan institut.

23. Matić, D. (2011). Islamski pokret u arapskom svijetu: uzroci, teme i politički značaj. Socijalna ekologija, 20 (1): 31-54.

24. Matić, D. i Bilandžić, M. (2010). Politički islam i mogućnost demokratizacije arapskog svijeta: slučaj Egipta. Polemos, 13 (2): 33-57.

25. Moore, K.; Mason, P. and Lewis, J. (2008). Images of Islam in the UK: The Representation of British Muslims in the National Print News Media 2000-2008. Cardiff School of Journalism, Media and Cultural Studies. Pregledano 10. studenog 2011. (http://www.channel4.com/news/media/pdfs/Cardiff\%20Final\%20Report.pdf).

26. Nalborczyk, A. S. (2004). The Image of Islam and Muslims in the Polish Mass Media before and after 11 September 2001. TRANS Internet-Zeitschrift für Kulturwissenschaften, 15. Pregledano 11. siječnja 2012. (http://www.inst.at/ trans/15Nr/01 4/nalborczyk15.htm).

27. Pace, E. (2009). Zašto religije ulaze u rat? Zagreb: Golden marketing - Tehnička knjiga.

28. Richardson, J. E. (2006). On delineating "reasonable" and "unreasonable" criticisms of Muslims. Fifth Estate Online, August. Pregledano 15. kolovoza 2009. (www.fifth-estate-online.co.uk/criticsm/ondelineatingreasonableandunreasonable.html).

29. Richardson, J. E. (2001). British Muslims in the Broadsheet Press: a challenge to cultural hegemony? Journalism Studies, 2 (2): 221-242.

30. Robertson, R. (1989). Globalization, politics, and religion, in:. Beckford James and Luckmann Thomas (Eds.). The changing face of religion. London: Sage:10-23.

31. Saeed, A. (2007). Media, Racism and Islamophobia: The Representation of Islam and Muslims in the Media. Sociology Compass, 1 (2): 443-462.

32. Savage, T. (2004). Europe and Islam: Crescent Waxing, Cultures Clashing. The Washington Quarterly, 27 (3): 25-50.

33. Shadid, W. and van Koningsveld, P. S. (2002). The Negative Image of Islam and Muslims in the West: Causes and Solutions, in: Shadid Wasif and van Koningsveld Sjoerd (Eds.). Religious freedom and the neutrality of the state: the position of Islam in the European Union. Leuven: Peeters: 174-194.

34. Tafra, A. (2009). Križarski ratovi i diskurs filozofije povijesti. Filozofska istraživanja, 29 (4): 709-717.

35. Turner, B. S. (2010). Islam, Diaspora, and Multiculturalism, in: Ahmed Akbar S. and Sonn Tamara (Eds.). The Sage Handbook of Islamic Studies. London: Sage: 17-33.

36. Vrcan, S. (2006). A Preliminary Challenge: Borders or Frontiers? Social Compass, 53 (2): 215-226.

37. Vrcan, S. (2001). Vjera u vrtlozima tranzicije. Split: Glas Dalmacije - revija Dalmatinske akcije. 
Goran Goldberger

Institute for Social Research in Zagreb, Croatia

e-mail: goran@idi.hr

\title{
Representation of Islam and Muslims in Croatian Daily Newspapers from 1990 to 2006
}

\begin{abstract}
In this paper the author presents the global and the Croatian social context in which Islam and Muslims are immersed, then the way they are represented in the media, as well as the research goal and methodology. The content analysis of Croatian daily newspapers from the two recent periods of Croatian history (1990-1998 and 1999-2006) shows that newspapers greatly contributed to the public image of Islam and Muslim activities in Croatia and in the world, based on the events from that specific time and place. Thematically, newspapers conveyed the politicization of Islam and a broader socio-political context. In the first period the most explored subjects were the war, war crimes and court trials, while human and religious rights, intolerance and protests dominated the second period. Terrorism and war on terror became increasingly relevant topics. While in the first period the focus was equally on Croatia and former Yugoslav states, in the second period it shifted to Europe and the rest of the world. Journalists used the recontextualization strategy, but also helped to understand that autochtonous Muslims in Croatia could be a useful bridge between Europe and the Muslim world.
\end{abstract}

Key words: Croatian daily newspapers, content analysis, identity, democratization, nationalism, deprivatization and politicization of religion, political Islam, fundamentalism. 